\title{
Evaluating iron deficiency anaemia in the third trimester of pregnancy with haematological parameters and serum ferritin concentration
}

\author{
Niranjani Selva Muthukumaran, Radha B. P. Thangappah*, Amrin Azad, Kesari Sravaniy
}

Department of Obstetrics and Gynecology, Meenakshi Medical College and Research Institute, Kancheepuram, Tamil Nadu, India

Received: 04 July 2019

Accepted: 08 August 2019

*Correspondence:

Dr. Radha B. P. Thangappah,

E-mail: radhaprabhu54@ymail.com

Copyright: ( $)$ the author(s), publisher and licensee Medip Academy. This is an open-access article distributed under the terms of the Creative Commons Attribution Non-Commercial License, which permits unrestricted non-commercial use, distribution, and reproduction in any medium, provided the original work is properly cited.

\begin{abstract}
Background: Iron deficiency is the commonest cause of anaemia and at least half of anaemia cases will have causes other than iron deficiency. The objective of this study was to determine the prevalence of iron deficiency anaemia among antenatal mothers based on haematological parameters and serum ferritin levels.

Methods: This was a hospital based cross sectional study, conducted at Meenakshi Medical College and Research Institute, Kancheepuram from January 2017 to June 2018. Two hundred antenatal mothers who were diagnosed with anaemia in the third trimester of pregnancy were evaluated by haematological parameters and serum ferritin assay.

Results: $38 \%$ of women had mild anaemia, $50 \%$ had moderate anaemia and $12 \%$ had severe anaemia. On peripheral smear, $60 \%$ had microcytic hypochromic anaemia indicating iron deficiency, and $12 \%$ had megaloblastic anaemia. In $41 \%$ of cases, the mean corpuscular volume was $<82 \mathrm{fL}$ indicative of iron deficiency. Among the 120 women diagnosed with iron deficiency anaemia on smear, the mean ferritin level was $16.62 \pm 73.42$ (less than $30 \mu \mathrm{g} / \mathrm{l}$ ). There was a statistically significant low levels of serum ferritin levels in those diagnosed with iron deficiency anaemia $(\mathrm{P}<$ $0.05)$. The serum ferritin level was $>160 \mu \mathrm{g} / \mathrm{lit}$ in $19 \%$ of cases.

Conclusions: Based on the haematological parameters and serum ferritin estimation, in $60 \%$ of cases, anaemia was due to iron deficiency. Before initiating treatment, it is important to differentiate various types of anaemia, so that appropriate treatment can be given.
\end{abstract}

Keywords: Iron deficiency anaemia, Peripheral smear, Pregnancy, Red cell indices, Serum ferritin

\section{INTRODUCTION}

The World Health Organization (WHO) defines anaemia in pregnant women as haemoglobin concentration less than $11 \mathrm{gm} / \mathrm{dl}$. Globally, the prevalence of anaemia in pregnant women was estimated to be $38 \% .{ }^{1}$ According to the WHO report, in 2011, 54\% of pregnant women were found to be anaemic. ${ }^{2}$ Among the South Asian countries, India has the highest prevalence of anaemia in pregnancy. ${ }^{3}$ In a study by Agarwal et al, $84 \%$ of pregnant and $92.2 \%$ of lactating women were anaemic. ${ }^{4}$ Other Indian studies also show a high prevalence of anaemia among pregnant mothers. ${ }^{5}$ Iron deficiency is the commonest cause of anaemia in the world. Folic acid, riboflavin, vitamins A and B12 deficiency can also lead to anaemia either alone or in association with iron deficiency. In recent years B12 deficiency has been highlighted as a cause of anaemia. ${ }^{6}$ Infections such as malaria, tuberculosis, chronic blood loss, worm infestation, haemorrhoids and inherited and acquired disorders that affect the haemoglobin synthesis are the other causes of anaemia which may complicate pregnancy. About 50\% of cases of anaemia are considered to be due to iron deficiency and at least half of anaemia cases will have causes other than iron deficiency. ${ }^{2}$ 
Globally, iron deficiency ranks number 9 among the 26 risk factors included in the Global Burden of Disease (GBD) 2000 Project. $^{7}$ Anaemia resulting from iron deficiency, causes fatigue and low productivity and when it occurs in pregnancy there is increased risk of maternal and perinatal morbidity and mortality. ${ }^{8}$ India contributes to about $80 \%$ of maternal deaths due to anemia in South Asia. ${ }^{9}$ Iron deficiency, manifesting with or without anaemia, can affect both the mother and their offspring. ${ }^{10}$ The commonly used methods to determine the cause and type of anaemia are red cell indices and peripheral smear. Bone marrow aspiration for haemosiderin is considered the gold standard for the diagnosis of iron deficiency, but, it is an invasive procedure. At the laboratory level, serum ferritin estimation is used for the diagnosis of iron deficiency anaemia and is widely used in pregnancy also. ${ }^{11}$

The objective of this study was to determine the prevalence of iron deficiency anaemia among antenatal mothers based on haematological parameters and serum ferritin levels.

\section{METHODS}

This was a hospital based cross sectional study, conducted at Meenakshi Medical College and Research Institute, Kancheepuram, from January 2017 to June 2018. Convenience sampling technique was used. The study population included 200 antenatal mothers who were diagnosed with anaemia in whom the haemoglobin level was less than $11 \mathrm{gm} / \mathrm{dl}$. Pregnant women with singleton pregnancies, more than 28 weeks of gestation, and those who were willing to participate were included in the study. Women with multiple pregnancies, those suffering from acute or chronic infections or rare types of anaemia and those who had elevated $\mathrm{C}$ - reactive protein were excluded from the study. The subjects were explained about the objective and benefits of the study and consent was obtained. Ethical Committee clearance was obtained from the Institutional Review Board.

Using a structured questionnaire, detail history was taken with regards to demographic details; age, socio-economic class, occupation, residence, educational level, obstetric history, nutritional status, medication history, previous treatment with iron preparations and blood, history suggesting predisposing factors for anaemia and family history. A thorough general and obstetric examination was carried out.

The laboratory tests involved testing for various haematological parameters, serum ferritin and c-reactive protein (CRP) levels. The venous blood samples were taken as per the standard procedure. Haemoglobin estimation, red cell count and packed cell volume and mean corpuscular volume (MCV), mean corpuscular haemoglobin $(\mathrm{MCH})$ and mean corpuscular haemoglobin (MCHC) were measured on the same day on whole blood using automated blood cell counter. Based on the red cell indices, iron deficiency anaemia was diagnosed if the MCV was $<82 \mathrm{fl}$. For the peripheral smear study, slides were prepared as per protocol. On peripheral smear, iron deficiency anemia was diagnosed by the presence of hypochromic and microcytic picture. Other features of iron deficiency anaemia such as anisocytosis and poikilocytosis were also noted. Megaloblastic anaemia was diagnosed by identifying megaloblasts and hyper segmented neutrophils. For the determination of serum ferritin and $\mathrm{C}$ - reactive protein, the sera was separated and were stored at -200 prior to assay in batches. Serum ferritin concentration was determined by electro chemiluminescence immunoassay method using mispa-i2 kit. Serum ferritin level $<30 \mu \mathrm{g} / \mathrm{lit}$ was considered diagnostic of iron deficiency anaemia. RHELAX - CRP slide test was used for the detection of CRP. Women whose CRP was greater than $6 \mathrm{mg} / \mathrm{L}$ were excluded from the study in order to rule out an inflammatory process that could influence the ferritin levels. Apart from the haematological and biochemical investigations, all mothers were investigated for worm infestations and urinary tract infections.

\section{Statistical analysis}

Data were analyzed using SPSS software version 21. The quantitative variables were expressed as mean and standard deviations. The qualitative variables were compared by the Pearson chi-square test. The comparison of quantitative variables with normal distribution was carried out using the Student's T test for independent series; And the Mann Whitney test for asymmetric distribution variables. $\mathrm{P}$ value of $<0.05$ was considered significant.

\section{RESULTS}

During the study period, anaemia complicating pregnancy was observed in $64 \%$ of all mothers. The study population consisted of 200 pregnant mothers who were diagnosed with anaemia in the third trimester of pregnancy. The age of the study population ranged between 19 to 38 years with a mean age of $25.49 \pm 4.014$. There were four cases of teen age pregnancy in this study. $28 \%$ of mothers were in their first pregnancy, $66 \%$ were in their second and third pregnancy and $6 \%$ were in their fourth pregnancy. $86 \%$ of women were between 33 to 40 weeks of gestation, $3 \%$ were between 28 to 32 weeks of gestation and $11 \%$ were beyond 40 weeks of gestation. $99 \%$ of mothers belonged to socio-economic class II and III and only two patients were in socioeconomic class IV and there were no women in class I group (Table 1$)$. The mean haemoglobin $(\mathrm{Hb})$ value in this study was $8.8 \mathrm{~g} / \mathrm{dl} \pm 1.299$ and the range was $5.5 \mathrm{~g} / \mathrm{dl}$ to $10.9 \mathrm{~g} / \mathrm{dl}$. The mean values of all red cell indices is shown in (Table 2). On analysing the severity of anaemia, $38 \%$ of women had mild anaemia $(9.1-11 \mathrm{gm} / \mathrm{dl}), 50 \%$ had moderate anaemia $(7.1-9 \mathrm{gm} / \mathrm{dl})$ and $12 \%$ had severe anaemia (less than $7 \mathrm{gm} / \mathrm{dl}$ ), according to the WHO classification. 
Table 1: Descriptive analysis showing the demographic and obstetric details.

\begin{tabular}{|lll|}
\hline \multicolumn{2}{|l|}{ No. } & Percentage \\
\hline$<19$ & 4 & \\
\hline $20-24$ & 96 & $2 \%$ \\
\hline $25-29$ & 66 & $38 \%$ \\
\hline $30-34$ & 22 & $11 \%$ \\
\hline 35 and above & 12 & $06 \%$ \\
\hline Obstetric score & & \\
\hline Gravida 1 & 56 & $28 \%$ \\
\hline Gravida 2 & 76 & $38 \%$ \\
\hline Gravida 3 & 56 & $28 \%$ \\
\hline Gravida 4 & 12 & $06 \%$ \\
\hline Socio-economic status & & \\
\hline Class I & 0 & $0 \%$ \\
\hline Class II & 104 & $52 \%$ \\
\hline Class III & 94 & $47 \%$ \\
\hline Class IV & 2 & $01 \%$ \\
\hline Gestational age & & \\
\hline $28-32$ weeks & 6 & $03 \%$ \\
\hline $33-36$ weeks & 52 & $26 \%$ \\
\hline $37-40$ weeks & 120 & $11 \%$ \\
\hline 40 weeks and more & 22 & \\
\hline
\end{tabular}

Based on the peripheral smear study, $60 \%$ of the anaemic mothers had microcytic hypochromic smear, $27 \%$ had normocytic normochromic anemia, $12 \%$ had macrocytic smear with hypersegmented neutrophils, and were diagnosed with megaloblastic anaemia and one had both microcytic hypochromic and macrocytic smear, diagnosed with dimorphic anaemia. The mean MCV in this study was $89.47 \mathrm{fL} \pm 15.712$. In 82 cases, the MCV was low $<82 \mathrm{fL}$, and in 74 of them there was microcytic picture on smear and the serum ferritin was $<30 \mu \mathrm{g} / \mathrm{lit}$.

In 40 patients, the MCV was >96fL and in 24 of them there was macrocytic picture on the peripheral smear. The mean serum ferritin concentration was $88.18 \pm 117.289 \mu \mathrm{g} / \mathrm{lit}$ and the range was 1 to $584 \mu \mathrm{g} / \mathrm{lit}$. On analysing the serum ferritin distribution, in $60 \%$ of cases, the serum ferritin level was $<30 \mu \mathrm{g} / \mathrm{lit}$, within normal range in $21 \%$ of cases, the levels were between 160$320 \mu \mathrm{g} / \mathrm{lit}$ in $10 \%$ cases and was $>320 \mu \mathrm{g} / \mathrm{lit}$ in $9 \%$ of cases (Table 3). The stool examination and urine culture results were all negative. The association between different types of anaemia diagnosed by peripheral smear study was correlated with mean serum ferritin levels.

Table 2: The result of red cell indices.

\begin{tabular}{|ll|llll|}
\hline & N & Minimum & Maximum & Mean & Std. deviation \pm \\
\hline Hb gm/dl & 200 & 5.5 & 10.9 & 8.804 & 1.2990 \\
\hline PCV \% & 200 & 17.6 & 42.0 & 28.101 & 4.9882 \\
\hline RBC mill/cu.mm & 200 & 2.1 & 5.1 & 3.304 & 0.5996 \\
\hline MCV fL & 200 & 60.0 & 127.0 & 89.468 & 15.7126 \\
\hline MCH pg & 200 & 15 & 42 & 27.86 & 5.385 \\
\hline MCHC \% & 200 & 25 & 46 & 31.26 & 3.504 \\
\hline
\end{tabular}

Table 3: The results of haematological and biochemical parameters.

\begin{tabular}{|lll|}
\hline & No. & Percentage \\
\hline Haemoglobin estimation & 76 & $38 \%$ \\
\hline Mild anaemia & 100 & $50 \%$ \\
\hline Moderate anaemia & 24 & $12 \%$ \\
\hline Severe anaemia & & $60 \%$ \\
\hline Peripheral smear results & 120 & $27 \%$ \\
\hline Microcytic hypochromic & 54 & $12 \%$ \\
\hline Normocytic normochromic & 24 & $01 \%$ \\
\hline Macrocytic with hypersegmented neutrophils & 2 & \\
\hline Microcytic hypochromic and macrocytic smear & & $41 \%$ \\
\hline Mean corpuscular volume fL & 82 & $39 \%$ \\
\hline$<82$ & 78 & $20 \%$ \\
\hline $83-95$ & 40 & $60 \%$ \\
\hline$>96$ & & $21 \%$ \\
\hline Serum Ferritin level & 120 & $10 \%$ \\
\hline$<30 \mu g / l i t$ & 42 & $09 \%$ \\
\hline $31-160 \mu g / l i t$ & 20 & \\
\hline $161-320 \mu g / l i t$ & 18 & \\
\hline$>320 \mu g / l i t$ & & \\
\hline
\end{tabular}


Table 4: The association between the type of anaemia and serum ferritin concentration.

\begin{tabular}{|c|c|c|c|c|}
\hline \multirow{2}{*}{ Type of anaemia based on peripheral smear study } & \multicolumn{3}{|c|}{ Serum Ferritin levels $\mu \mathrm{g} / \mathrm{l}$} & \multirow{2}{*}{ P Value } \\
\hline & $\mathbf{N}$ & Mean & $\mathbf{S D} \pm$ & \\
\hline Hypochromic Microcytic anaemia & 120 & 16.62 & 73.46 & \multirow{4}{*}{0.0001} \\
\hline Normochromic Normocytic anaemia & 54 & 64.76 & 98.18 & \\
\hline Megalolastic anaemia & 24 & 313.68 & 33.19 & \\
\hline Microcytic and Megalolastic anaemia & 2 & 28 & - & \\
\hline
\end{tabular}

Table 5: The distribution of serum ferritin levels in different types of anaemia.

\begin{tabular}{|c|c|c|c|c|}
\hline \multirow{2}{*}{ Type of anaemia by smear } & \multicolumn{4}{|c|}{ Serum Ferritin concentration $\mu g /$ lit } \\
\hline & $<30$ & 31-160 & 161-320 & $>320$ \\
\hline Hypochromic microcytic anaemia & 110 & 8 & & 2 \\
\hline Normocytic normochromic anemia & 8 & 34 & 10 & 2 \\
\hline Megaloblastic anaemia & & & 10 & 14 \\
\hline Dimorphic anaemia & 2 & & & \\
\hline
\end{tabular}

Among the 120 women diagnosed with iron deficiency anemia, the mean ferritin level was $16.62 \pm 73.42$ (less than $30 \mu \mathrm{g} / \mathrm{l}$ ) and in 54 women who were diagnosed with anemia of chronic disease, the mean ferritin level was $64.76 \pm 98.18 \mu \mathrm{g} / \mathrm{l}$, while in 24 women diagnosed with megaloblastic anemia, the mean ferritin level was $313.68 \pm 33.19$. There was a statistically significant low levels of serum ferritin levels in those diagnosed with iron deficiency anaemia. $(\mathrm{P}<0.05)$ (Table 4).

On analysing the distribution ferritin concentration in different types of anaemia, it was seen that among the 120 smears reported as hypochromic microcytic anaemia, in 110 patients, the serum ferritin level was $<30 \mu \mathrm{g} / 1$, was within the normal range in 8 patients. In two patients, the serum ferritin level was high with $584 \mu \mathrm{g} / \mathrm{l}$ indicating iron over load. These cases were subsequently diagnosed as thalassemia on electrophoresis. In 54 patients reported with normocytic normochromic anemia, there was diminished iron stores in 8 patients, and in two patients the level was $>300 \mu \mathrm{g} / \mathrm{l}$. There were 24 patients diagnosed with megaloblastic anemia and in 14 of them, the serum ferritin levels were $>300 \mu \mathrm{g} / \mathrm{l}$ (Table 5). On statistical analysis, women with low ferritin levels $(<30 \mu \mathrm{g} / \mathrm{l})$ were more prone to haemogram abnormalities with a statistically significant difference $(p<0.0001)$ seen in iron deficiency anaemia.

\section{DISCUSSION}

The diagnosis of anaemia, it's severity and the type of anaemia are based primarily on the haemoglobin estimation, PCV, red cell indices, peripheral smear, and serum ferritin concentration. In this study moderate anaemia was the predominant finding seen in 50\% and severe anaemia was seen in $12 \%$ of cases. In order to ascertain the possible type and cause of anaemia we have looked at three parameters namely; the peripheral smear, MCV and the serum ferritin levels. Iron deficiency is the most common micronutrient deficiency in the world and is the most common cause of anaemia. ${ }^{12}$ For the diagnosis of iron deficiency anaemia, the commonly used tests are peripheral smear and MCV. In our study, on peripheral smear, $60 \%$ were diagnosed with hypochromic microcytic anemia and $12 \%$ were diagnosed with megaloblastic anaemia.

Although iron deficiency is the most common cause of microcytic anemia, there are also other causes such as chronic inflammatory states, lead poisoning, thalassemia, and sideroblastic anemia. ${ }^{13}$ Among the 120 patients diagnosed with microcytosis, in 110 of them the serum ferritin level was also $<30 \mu \mathrm{g} / \mathrm{lit}$, thereby confirming the diagnosis of iron deficiency anaemia. However, in two patients, the ferritin level was $587 \mu \mathrm{g} / \mathrm{lit}$. indicating iron overload, and this case was subsequently diagnosed as a case of thalassemia. In up to 40 percent of patients with iron deficiency anemia, peripheral smear may show normocytic erythrocytes. ${ }^{14}$ In our study, among the 54 patients diagnosed with normocytic normochromic anaemia, in 8 of them, the serum ferritin concentration was $<30 \mu \mathrm{g} / \mathrm{lit}$. and the MCV was $<82 \mathrm{fL}$. The above finding indicates that even in the presence of normal smears, iron deficiency can exist. Though red cell indices are late manifestations of anaemia they are also useful tests to know the type of anaemia.

Among the 120 cases diagnosed with hypochromic microcytic anaemia on peripheral smear, only in 74 patients the MCV was low, within normal range in 42 cases and in four cases the MCV was >96fL. However, all the 24 cases diagnosed with macrocytic anaemia had raised levels of MCV indicating that, based on MCV and smear reports macrocytic anaemia can be diagnosed. Plasma ferritin is an indirect marker of the total amount of iron stored in the body. At the laboratory level, serum ferritin estimation is used for the diagnosis of iron deficiency anaemia. ${ }^{15}$ 
WHO/CDC technical guidance recommends that in the absence of infection, serum ferritin or serum transferrin receptor in combination with haemoglobin provides the best approach to measuring iron status in general population. ${ }^{16}$ The reference range of serum ferritin for women is $80-160 \mathrm{ng} / \mathrm{ml}$. Various threshold for serum ferritin levels have been used to define iron deficiency. ${ }^{17}$ In order to account for the increase in ferritin values caused by inflammation, rising the cut off level to $30 \mu \mathrm{g} / \mathrm{l}$ to define iron deficiency has been suggested by WHO. ${ }^{18}$ Giving consideration for pregnancy related proinflammatory changes, UK, uses a threshold level of $<30 \mathrm{ng} / \mathrm{ml} .{ }^{19}$ We have also used a threshold of $<30 \mu \mathrm{g} / \mathrm{l}$ to define iron deficiency anaemia. In areas of widespread infection, WHO recommends concurrent measurement of two acute phase proteins, namely C-reactive protein (CRP) and $\alpha 1$ acid glycoprotein (AGP) in the interpretation of serum ferritin values. ${ }^{15}$ In our study, those with elevated CRP were excluded from the study. In the absence of inflammation, high serum ferritin levels $>150 \mu \mathrm{g} / \mathrm{l}$ indicates severe risk of iron overload. ${ }^{15}$ In this study, in 38 patients the serum ferritin level was $>160 \mu \mathrm{g} / \mathrm{l}$. All of them have received multiple courses of parenteral iron and blood transfusions in the past. Only in eight patients electrophoresis was possible and thalassemia was diagnosed in two of them. In 24 patients with megaloblastic anaemia on smear, the mean serum ferritin level was $313.68 \mu \mathrm{g} / \mathrm{l}$. These findings suggest that most of the patients presenting with anaemia are being treated as iron deficiency anaemia.

The second global nutrition target for 2025 is to reduce the prevalence of anaemia by $50 \%$ among women of reproductive age. ${ }^{20}$ To achieve this goal, it is important to identify the various factors contributing to anaemia and treat appropriately. In clinical practice, haemoglobin and $\mathrm{MCV}$ are considered as the screening test for iron deficiency anaemia. ${ }^{11,21}$ Estimating ferritin levels would be required for those with history of anaemia in previous pregnancy, multiparity, vegetarians, teen-age pregnancy, and those presenting with resistant anaemia. ${ }^{11}$

\section{CONCLUSION}

Based on the haematological parameters and serum ferritin estimation, our study has shown that only $60 \%$ of anaemia are due to iron deficiency and in another $40 \%$ of cases, there are other causes such as megaloblastic anaemia, thalassemia etc. Before initiating treatment, it is important to differentiate these various types of anaemia, so that appropriate treatment can be given. In developing countries, most often, all anaemia are presumed to be due to iron deficiency and treated with iron preparations. This may result in other types of anaemia being missed, and unwarranted parenteral iron use in these patients can lead to potential complications due to iron over load.

As it is not possible to do ferritin estimation in all mothers, the initial diagnosis and management should be based on the peripheral smear and the MCV results. If the patient is not responding to iron therapy, then, it is mandatory that serum ferritin level is estimated before further treatment. This approach will help in identifying other causes of anaemia as well as to prevent iron overload.

\section{ACKNOWLEDGMENTS}

Authors would like to thank the dean of Meenakshi Medical College and Research Institute for granting permission and rendering help in conducting this research. Authors also acknowledge and thank the Professor and technical staffs of Biochemistry Department of Meenakshi Medical College for rendering their technical support in conducting the tests.

\section{Funding: No funding sources}

Conflict of interest: None declared

Ethical approval: The study was approved by the Institutional Ethics Committee

\section{REFERENCES}

1. Stevens GA, Finucane MM, De-Regil LM. Global, and national trends in haemoglobin concentration and prevalence of total and severe anaemia in children and pregnant and non-pregnant women for 1995-2011: a systematic analysis of populationrepresentative data. The Lancet Global Health. 2013;1:e16-e25.

2. WHO. The Global Prevalence of Anaemia in 2011. Geneva. World Health Organization; 2015. Available at: https://apps.who.int/iris/handle/10665/177094 Accessed on $22^{\text {nd }}$ February 2019.

3. WHO Global Database on Anaemia. Worldwide Prevalence of Anaemia 1993-2005. Geneva, Switzerland: World Health Organization; 2008. Available

at: https://www.who.int/nutrition/publications/micronutr ients/anaemia_iron_deficiency/9789241596657/en/ Accessed on $22^{\text {nd }}$ February 2019.

4. Agarwal KN, Agarwal DK, Sharma A, Sharma K, Prasad K, Kalita MC, et al. Prevalence of anaemia in pregnant and lactating women in India. Indian $\mathrm{J}$ Med Res. 2006;124:173-84.

5. Mangla M, Singla D. Prevalence of anaemia among pregnant women in rural India: a longitudinal observational study. IJRCOG. 2016;5(10):3599-05.

6. Yajnik CS, Deshpande SS, Jackson AA, Refsum H. Vitamin B12 and folate concentrations during pregnancy and insulin resistance in the offspring: the Pune Maternal Nutrition Study. Diabetolgia. 2008;51:29-36.

7. Stoltzfus RJ, Iron deficiency: Global prevalence and consequences. Food and Nutrition bulletin. 2003;24(4):S99-S103.

8. WHO/UNICEF/UNU, Iron deficiency anemia, assessment, prevention and control, Geneva, Switzerland, WHO, 2001. Available at: https://www.who.int/nutrition/publications/en/ida_as 
sessment_prevention_control.pdf Accessed on $22^{\text {nd }}$ February 2019.

9. Ezzati M, Lopez AD, Rodgers A, Hoorn SV, Murray C. Selected major risk factors and global and regional burden of disease. Lancet. 2002;360:134760 .

10. Acosta CD, Kurinczuk JJ, Lucas DN. Severe maternal sepsis in the UK, 2011-2012: a national case-control study. PLoS Medicine. 2014;11:e1001672.

11. Pavord S, Myers B, Robinson S. UK guidelines on the management of iron deficiency in pregnancy. $\mathrm{Br}$ J Haematol. 2012;156:588-600.

12. Kassebaum NJ. The global burden of anemia. Hematol Oncol Cin N Am. 2016;30:247-3018.

13. World Health Organization. Iron Deficiency Anaemia: Assessment, Prevention, and Control: A Guide for Programme Managers. Geneva, Switzerland: World Health Organization; 2001. Available at: https://www.who.int/nutrition/ publications/en/ida_assessment_prevention_control.p df. Accessed on $22^{\text {nd }}$ February 2019.

14. Matthew WS, Jason ED. Iron deficiency anemia: evaluation and management. Am Fam Physician. 2013;87(2):98-104.

15. WHO. Serum ferritin concentrations for the assessment of iron status and iron deficiency in populations. Vitamin and Mineral Nutrition Information System. Geneva, World Health Organization, 2011 (WHO/MH/NHD/MNM/11.2). Available at: https://www.who.int/vmnis/indicators /serum_ferritin.pdf. Accessed on $22^{\text {nd }}$ February 2019.

16. WHO/CDC: Assessing the iron status of populations: including literature reviews: report of a joint WHO/CDC Technical consultation on the Assessment of iron status at the Population Level. In. Geneva: World Health Organization/ Centers for Disease Control and Prevention; 2007. Available at: https://www.who.int/nutrition/publications/micronutr ients/anaemia_iron_deficiency/9789241596107.pdf Accessed on $22^{\text {nd }}$ February 2019.
17. Daru J, Allotey J, Pena-Rosas JP, Khan KS. Serum ferritin thresholds for the diagnosis of iron deficiency in pregnancy: a systematic review. Transfusion Med. 2017;27(3):167-74.

18. WHO/CDC. Assessing the iron status of populations: Including literature reviews: report of a joint World Health Organization / Centers for Disease Contol and Prevention technical consultation on the assessment of iron status at the population level. Geneva, World Health Organization, 2004. Available at: https://www.who.int/nutrition/publications/micronutr ients/anaemia_iron_deficiency/9789241596107.pdf Accessed on $22^{\text {nd }}$ February 2019.

19. Skikne BS, Punnonen K, Caldron PH. Improved differential diagnosis of anemia of chronic disease and iron deficiency anemia: a prospective multicenter evaluation of soluble transferrin receptor and the sTfR/log ferritin index. Am J Hematol. 2011;86(11):923-7.

20. Global Nutrition Targets 2015: anaemia policy brief. Geneva: World Health Organization; 2014 (WHO/NMH/NHD/14.4) Available at: https://www.who.int/nutrition/publications/globaltarg ets2025_policybrief_anaemia/en/. Accessed on $22^{\text {nd }}$ February 2019.

21. Rukuni R, Knight M, Stanworth SJ. Screening for iron deficiency and iron deficiency anaemia in pregnancy: a structured review and gap analysis against UK national screening criteria. BMC Pregnancy Childbirth. 2015;15:269.

Cite this article as: Muthukumaran NS, Thangappah RBP, Azad A, Sravaniy K. Evaluating iron deficiency anaemia in the third trimester of pregnancy with haematological parameters and serum ferritin concentration. Int J Reprod Contracept Obstet Gynecol 2019;8:3744-9. 